\title{
Etniske forskjeller i insulinresistens i svangerskapet
}

\section{I første del av svangerskapet er kvinner fra Øst- og Sør-Asia mer insulin- resistente enn kvinner fra Vest-Europa.}

For å sikre næringsstoffer til fosteret blir gravide kvinner mer og mer resistente for insulin utover i svangerskapet. Betacellene kompenserer for dette ved å skille ut mer insulin. Dersom ikke betacellene klarer å kompensere tilstrekkelig, kan resultatet bli at kvinnen får for høyt blodsukkernivå og svangerskapsdiabetes.

I en ny studie fra Stork Groruddalen-prosjektet beskriver vi endringer i insulinresistens og betacellefunksjon i og etter svangerskapet hos kvinner med ulik etnisk bakgrunn
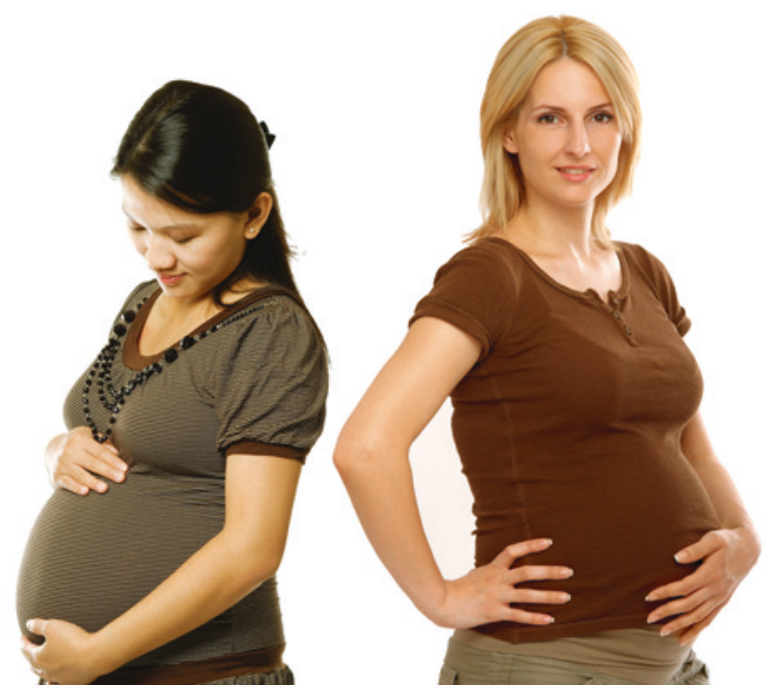

i Oslo, dvs. fra Vest-Europa (41\%), SørAsia (25\%), Midtøsten (15\%), Øst-Asia (6\%) og andre steder (13\%) (1). Kvinnene ble intervjuet og avga blodprøver i første del av svangerskapet, i svangerskapsuke $28 \mathrm{og}$ tre måneder etter fødsel. Ut fra verdiene for fastende glukose og C-peptid ble insulinresistens og betacellefunksjon beregnet.

Hovedfunnet var at kvinnene med etnisk bakgrunn fra Øst- og Sør-Asia var mer insulinresistente i første del av svangerskapet sammenliknet med kvinnene fra Vest-Europa. Fra første til siste del av svangerskapet ble alle kvinnene ca. 50\% mer insulinresistente. Kvinnene fra Øst- og Sør-Asia klarte ikke å kompensere for denne svangerskapsrelaterte insulinresistensen med økt betacellefunksjon i like stor grad som kvinnene fra Vest-Europa.

\section{Kåre I. Birkeland}

k.i.birkeland@medisin.uio.no

Avdeling for endokrinologi, sykelig overvekt og forebyggende medisin Oslo universitetssykehus

\section{Litteratur}

1. Mørkrid K, Jenum AK, Sletner L et al. Failure to increase insulin secretory capacity during pregnancy-induced insulin resistance is associated with ethnicity and gestational diabetes. Eur J Endocrinol 2012: 167: 579-88.

Publisert først på nett 14.12. 2012.

\section{Pasienter med nettilgang til sin e-journal}

\section{Mange pasienter synes de har nytte av å ha tilgang til sin elektroniske pasientjournal via en nettportal. Dette viser erfaringer fra USA.}

Ved tre store helsesentre i USA med til sammen 105 primærleger fikk flere enn 13500 pasienter tilgang til sin elektroniske journal via en nettportal (1). Bruken av tilbudet ble registrert elektronisk, og pasienter og leger besvarte et spørreskjema.

I løpet av ett år hadde $87 \%$ av pasientene åpnet minst ett journalnotat. Av de 5391 pasientene som besvarte spørreskjemaet, svarte mellom $77-87 \%$ ved de tre sentrene at de syntes tilgangen hjalp dem til å føle større kontroll over egen helse. $60-78 \%$ av dem som brukte legemidler, rapporterte at de i større grad tok medisinen som forskrevet. $20-42 \%$ hadde vist notatene til andre. $1-8 \%$ rapporterte om forvirring, engstelse eller harme. Omfanget av journalnotatene $ø k t e$ ikke. Noen leger rapporterte at de måtte bruke mer tid til å besvare spørsmål fra pasientene utenom konsultasjonen (0-5\%), at de endret måten notatene ble skrevet på (3-36\%) og at de brukte mer tid på notatene (0-21\%). Rundt én av tre pasienter ønsket å kunne godkjenne journalnotatene, mens $85-96 \%$ av legene var uenig i dette. $99 \%$ av pasientene ønsket å fortsette ordningen, og ingen leger valgte å slutte med den.

- Elektroniske journalsystemer og sikre nettportaler gjør det mulig å øke pasientenes involvering $i$ egen behandling, sier professor Pål Gulbrandsen ved Akershus universitetssykehus. - Men dette er ikke uten risiko, som resultatene viser. Forvirring, engstelse og harme er ikke godt for dem det rammer, sier han.

- Vi vet at pasienter er tjent med skriftlig oppsummering etter konsultasjoner. Å bruke journalen slik vil fungere best om legene bevisst utformer den for det formålet, og ikke bare som et arbeidsdokument eller for å skaffe seg juridisk ryggdekning, sier Gulbrandsen.

\section{Petter Gjersvik}

petter.gjersvik@gmail.com

Tidsskriftet

Litteratur

1. Delbanco T, Walker J, Bell SK et al. Inviting patients to read their doctors' notes: a quasi-experimental study and a look ahead. Ann Intern Med 2012: 157: $461-70$

Publisert først på nett 12.12. 2012. 